\title{
Possible protective effect of pomegranate peel powder on lung injury induced by skeletal muscle ischemia-reperfusion
}

\author{
Original \\ Article
}

\author{
Rasha Mamdouh Salama and Manar Ali Faried
}

Department of Anatomy and Embryology, Faculty of Medicine, Menoufia University, Egypt

\begin{abstract}
Introduction: Multi-organ failure with life-threatening sequel occurs in a variety of surgical practices as a result of ischemiareperfusion (I/R) injury.

Aim of work: In this study, more light is thrown on the histological lung changes induced by skeletal muscle $\mathrm{I} / \mathrm{R}$ with reference to their underlying mechanisms and to determine, for the first time, the protective role of pomegranate peel powder on the lung injury induced by skeletal muscle I/R.

Materials and Methods: Thirty adult male albino rats were divided equally into three groups: sham control group, I/R group and I/R group pretreated with pomegranate peel powder $(500 \mathrm{mg} / \mathrm{kg}$ dissolved in distilled water twice daily orally for 10 days). At the end of the experiment, blood samples were obtained to assess serum malondialdehyde (MDA) then lung specimens were processed for routine histological examination and detection of collagen deposition. Myeloperoxidase (MPO), a marker of neutrophils infiltration, transforming growth factor- $\beta$ (TGF- $\beta$ ), an inflammatory and pro-fibrotic mediator and $\mathrm{Bcl} 2$, an anti-apoptotic marker, were detected immunohistochemically.

Results: Loss of general architecture of the lung tissues, massive inflammatory infiltrate, emphysema, edema, congested blood vessels, thickened inter-alveolar septa, destruction of some alveoli, disorganization and focal sloughing of the bronchial epithelium in addition to increased collagen deposition were detected in $\mathrm{I} / \mathrm{R}$ group. Oxidative stress in the form of significant increase of MDA level in addition to up-regulation of both MPO and TGF- $\beta$ and down-regulation of Bcl 2 were implicated in the pathogenesis of acute lung injury induced by skeletal muscle I/R. Pomegranate peel powder significantly ameliorated these damaging effects through its antioxidant, anti-inflammatory, anti-fibrotic and anti-apoptotic effects.

Conclusion: Pretreatment of rats with pomegranate peel protected the lungs against skeletal muscle I/R injury.
\end{abstract}

Received: 01 May 2018, Accepted: 11 September 2018

Key Words: Ischemia-Reperfusion, lung, pomegranate peel.

Corresponding Author: Rasha Mamdouh Salama, M.D, Department of Anatomy and Embryology, Faculty of Medicine, Menoufia University, Egypt, Tel.: +2 01005240928, E-mail: drrashasalama@yahoo.com

ISSN: $1110-0559$, Vol. 41, No. 2

\section{INTRODUCTION}

With increasing incidence of either musculoskeletal trauma or malignant tumor, the need to reconstructive surgery techniques that preserve these affected regions is also in increase. Unfortunately, ischemia reperfusion (I/R) injury remains one of the major causes of multi-organ failure that may lead to fatal complications ${ }^{[1]}$.

Ischemia/reperfusion (I/R) injury occurs as a result of interruption of the blood flow with subsequent reperfusion leading to significant tissue damage ${ }^{[2]}$. Release of toxic metabolites and several inflammatory mediators into the systemic circulation occurs as a result of reperfusion of ischemic tissues than ischemia itself ${ }^{[3]}$. In addition, apoptotic changes, dysfunction of anti $\neg$ oxidant mechanisms, and injury of the protein, lipids, deoxyribonucleic acid (DNA) and mitochondria are incorporated in multi-organ damage and even failure ${ }^{[4]}$. One of the most important target organs in multiple organ failure caused by severe injury is the $\operatorname{lung}^{[5]}$.
Anti-oxidants may limit I/R induced injury in humans ${ }^{[6]}$. One of the important dietary sources of antioxidants is the pomegranate (Punicagranatum L.), belonging to the family Punicaceae ${ }^{[7]}$. Pomegranate has high antioxidant capacity and total polyphenol contents including ellagic acid, gallagic acid, punicalin, and punicalagin ${ }^{[8]}$. The peel is an important source of bioactive compounds such as phenolics, flavonoids, ellagitannins, and proanthocyanidin compounds, complex polysaccharides and minerals mainly potassium, nitrogen, calcium, phosphorus, magnesium and sodium $^{[9]}$. Punicalagin is the most abundant polyphenol and is mainly found in pomegranate pee ${ }^{[10]}$.

This study aims to determine, for the first time, the possible protective role of pomegranate peel powder on the lung injury induced by skeletal muscle I/R.

\section{MATERIALS AND METHODS}

Fresh pomegranate fruits were collected from the market and cleaned. The pomegranate peels were isolated, divided into small pieces and air dried. The dried peels 
were then grinded into fine powder that was stored in a clean airtight container ${ }^{[11]}$.

Thirty adult male albino rats, weighing 150-200 gms each, were used in this study. They were purchased from and the experiment was done in the animal house of Medical Research Institute, Alexandria University, Egypt. This study was conducted according to the guidelines of the animal care review board of the Faculty of Medicine, Menoufia University, Egypt and adhering to the guide for care and use of laboratory animals and the study was approved by the ethics committee.

\section{Experimental groups:-}

The rats were maintained under constant room temperature and standard conditions with ad libitum access to water and commercial food and were placed in individual plastic cages with soft bedding. Rats were divided equally into three groups of ten rats each:

Group I (sham control group):- The rats were subjected to all operative procedures, except arterial occlusion and reperfusion.

Group II (ischemia-reperfusion group):- The rats were subjected to 2 hours of ischemia followed by 24 hours of reperfusion.

Group III (ischemia-reperfusion + pomegranate peel group):- The rats in this group were pretreated with pomegranate peel powder $(500 \mathrm{mg} / \mathrm{kg}$ body weight $)$ that was dissolved in distilled water and given by oral intubation twice a day for 10 days before ischemia. On post-treatment day 11, rats underwent 2 hours hind limb ischemia by clamping the femoral artery, then the clamp was removed and the rat underwent 24 hours reperfusion.

\section{Surgery:-}

Anesthesia was induced using ketamine plus xylazine $(10 \mathrm{mg} / \mathrm{kg}$ and $50 \mathrm{mg} / \mathrm{kg}$ i.m., respectively). After induction of anesthesia, the left hind limb was completely clipped, disinfected and a skin incision was made on the medial surface of the left hind limb. The femoral artery was isolated and clamped with a vascular clamp for 2 hours. The rats were kept anesthetized throughout the duration of the ischemic period and body temperature was maintained with a heating pad over the body. Following the ischemic period, the vascular clamp was removed and then the surgical site was routinely closed. After the surgery, fluid losses were replaced by intraperitoneal administration of 5 $\mathrm{ml}$ warm isotonic saline and the rats were returned to their cages with ad libitum access to water and commercial food during the reperfusion period.

After 24 hours of reperfusion, the rats were anesthetized with an overdose of intraperitoneal pentobarbital injection $(300 \mathrm{mg} / \mathrm{kg})$ and the intracardiac blood samples were collected for biochemical analysis then the lungs were removed en bloc and fixed in 10\% neutral buffered formalin solution for histological and immunohistochemical examinations under light microscopy.

\section{Biochemical analysis}

Serum was obtained from the intracardiac blood samples by centrifugation. The serum concentration of malondialdehyde (MDA) is generally used as biomarker of lipid peroxidation that is used as an indicator of reactive oxygen species (ROS) mediated damage.

\section{Histological examination}

A midline thoraco-abdominal incision was performed to all rats and the lungs were removed and fixed in a $10 \%$ neutral buffered formalin solution then processed routinely by embedding in paraffin and sectioned into $5 \mu \mathrm{m}$ thick sections to be stained with hematoxylin and eosin for routine histological assessment and masson trichrome stain for detection of collagen deposition.

The severity of the lung injury was graded into four grades as follows: grade 0 , no diagnostic change; grade 1 , mild neutrophil leukocyte infiltration and mild to moderate interstitial congestion; grade 2, moderate neutrophil leukocyte infiltration, perivascular edema formation and partial destruction of pulmonary architecture; and grade 3, dense neutrophil leukocyte infiltration and complete destruction of pulmonary structure ${ }^{[12]}$. A total of five slides from each lung sample were randomly screened and the mean was accepted as the representative value of the sample.

\section{Immunohistochemistry}

Analysis of Myeloperoxidase (MPO), Bcl2 and transforming growth factor- $\beta$ (TGF- $\beta$ ):-

The paraffin sections on poly-L-lysin coated slides were deparaffinized and rehydrated. Endogenous peroxidase was blocked by inserting the sections in 3\% hydrogen peroxide $(\mathrm{H} 2 \mathrm{O} 2)$. The microwave antigen retrieval procedure was performed. The sections were incubated with primary anti MPO antibody (rabbit polyclonal, Lab Vision, USA), anti $\mathrm{Bcl} 2$ antibody (rabbit polyclonal, Abcam) and anti TGF- $\beta$ antibody (mouse monoclonal, Abam). After that, biotinylated goat-polyvalent secondary antibody was applied. The sections were then incubated in preformed streptavidin peroxidase and finally the prepared DAB substrate chromogen (3,3'-diaminobenzidine tetrahydrochloride) was applied and the slides were counterstained with hematoxylin to be examined under light microscope. This technique was performed in the Pathology Department, Faculty of Medicine, Menoufia University, Egypt.

\section{Morphometric analysis}

By using Image J program, version K 1.45 , thickness of inter-alveolar septa, percentage of surface area of collagen deposition in addition to percentage of positive MPO, Bcl2 and TGF- $\beta$ immunoreactive cells were measured.

For each parameter, ten non-overlapping fields ("x 20 for measuring the thickness and surface area" and "x 100 
for counting the immunohistochemical positive cells") for every specimen from five different rats/experimental group were examined. This was done in the Anatomy Department, Faculty of Medicine, Menoufia University, Egypt.

\section{Statistical analysis}

The data were collected, tabulated and analyzed by SPSS (statistical package for social science) version 17.0 on IBM compatible computer (SPSS Inc., Chicago, IL, USA). A $p$ value of $<0.05$ was considered statistically significant. A $p$ value of $<0.001$ was considered statistically highly significant and $P$ value $>0.05$ was considered nonsignificant. This was done in the Public Health Department, Faculty of Medicine, Menoufia University, Egypt.

\section{RESULTS:}

\section{Biochemical results:}

Serum level of MDA was significantly higher in $\mathrm{I} / \mathrm{R}$ group than both control and protected groups. Moreover, the protected group showed significant increase in MDA level when compared to the control group (Table 1, Histogram 1).

\section{Histological results:}

\section{Hematoxylin and Eosin stain (HxandE):-}

Light microscopic study of HxandE stained sections from the sham control group showed normal lung tissue with clear alveoli, thin inter-alveolar septa, blood vessels and normal bronchial epithelial lining (Fig. 1).

Ischemia reperfusion group (I/R) revealed loss of general architecture of the lung tissues, distorted appearance of lung parenchyma, massive inflammatory infiltrate, emphysema, edema, destruction with narrowing of some alveoli and compensatory dilatation of others. Moreover, congested blood vessels, deposition of brown particles within the lung tissue most probably hemosiderin deposition as a result of breakdown of red blood cells, thickening of inter-alveolar septa and destruction of others in addition to disorganization and focal sloughing of the bronchial epithelial lining were observed (Fig 2).

Pretreatment by pomegranate peel powder decreased the lung changes to a great extent. Lung parenchyma was more or less with normal architecture except for mild inflammatory infiltrate. Sloughing of small areas of the bronchial epithelium was also noted (Fig 3).

Statistically, the thickness of the inter-alveolar septa was significantly higher among I/R group than control and protected groups. Furthermore, there was a non-significant difference between both the control and protected groups (Table 2 and Histogram 2).

\section{Histopathology and lung injury score}

Grades 2 and 3 of lesions were obtained in I/R group (as seen morphologically in Fig. 2), with an average of
2.6. These pathological changes in $\mathrm{I} / \mathrm{R}$ group pretreated with pomegranate peel powder were much less than in $I / R$ group (as seen morphologically in fig.3) with an average 0.8 . There was a highly significant difference in the lung injury score between I/R group and both the control and protected groups with no statistical significance difference between the control and protected groups (Table 3).

\section{Masson trichrome stain}

Comparing to the control group, light microscopic study of masson trichrome stained sections showed moderate to massive increase in the collagen deposition within the lung tissue in I/R group that was decreased in the protected group (Fig. 4).

Statistically, there was a highly significant increase in the percentage of the surface area of collagen deposition in $\mathrm{I} / \mathrm{R}$ group when compared to both control and protected groups. Moreover, there was a significant difference between both the control and protected groups (Fig 4, Table 4).

\section{Immunohistochemical results:}

The immunohistochemical results were detected by brown discoloration either cytoplasmic or nuclear.

\section{Myeloperoxidase (MPO) immunoreaction:}

The immunohistochemical results revealed an increase in the MPO immunoreaction, an indicator of neutrophilic infiltration, in I/R group compared with both control and $\mathrm{I} / \mathrm{R}$ group pretreated with pomegranate peel powder. Statistically, the percentage of MPO positive cells was significantly higher in $\mathrm{I} / \mathrm{R}$ group than both control and protected groups. Moreover, there was a non-significant difference between the control and protected groups (Fig 5, Table 5).

\section{Bcl2 immunoreaction:}

The results showed a decrease in the Bcl2 immunoreaction, an anti-apoptotic marker, in I/R group. This was partially relieved in $\mathrm{I} / \mathrm{R}$ group pretreated with pomegranate peel powder. Statistically, the percentage of $\mathrm{Bcl} 2$ positive cells was significantly lower in I/R group than the other two groups. Furthermore, a non significant difference between both control and protected groups was observed (Fig 6, Table 5).

\section{Transforming growth factor- beta (TGF- $\beta)$ immunoreaction:}

Regarding the TGF- $\beta$, there was an increase in the number of positive cells in $\mathrm{I} / \mathrm{R}$ group in comparison to the other groups. This was partially improved in I/R group pretreated with pomegranate peel powder. Statistically, there was a significant increase in the percentage of TGF- $\beta$ positive cells in $\mathrm{I} / \mathrm{R}$ group when compared to the other two groups. Moreover, there was a significane difference between the control and protected groups (Fig 7, Table 5). 


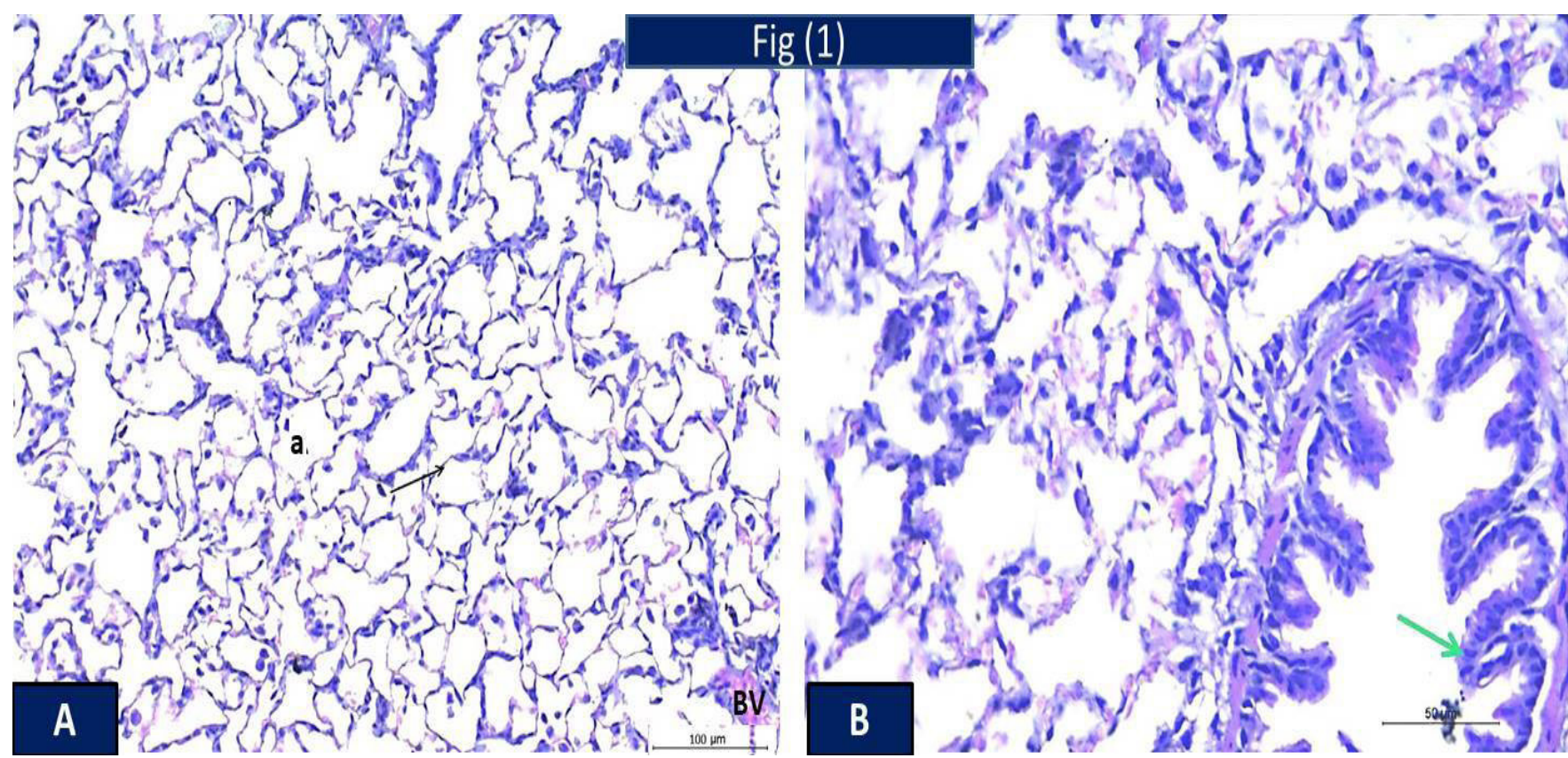

Fig 1: Photomicrographs of the control group:- (A): showing normal lung architecture with clear alveoli (a), blood vessels (BV) and thin inter-alveolar septa (black arrow) (HxandE X 20). (B): Normal bronchial epithelial lining (green arrow) is clearly seen (HxandE X 40).

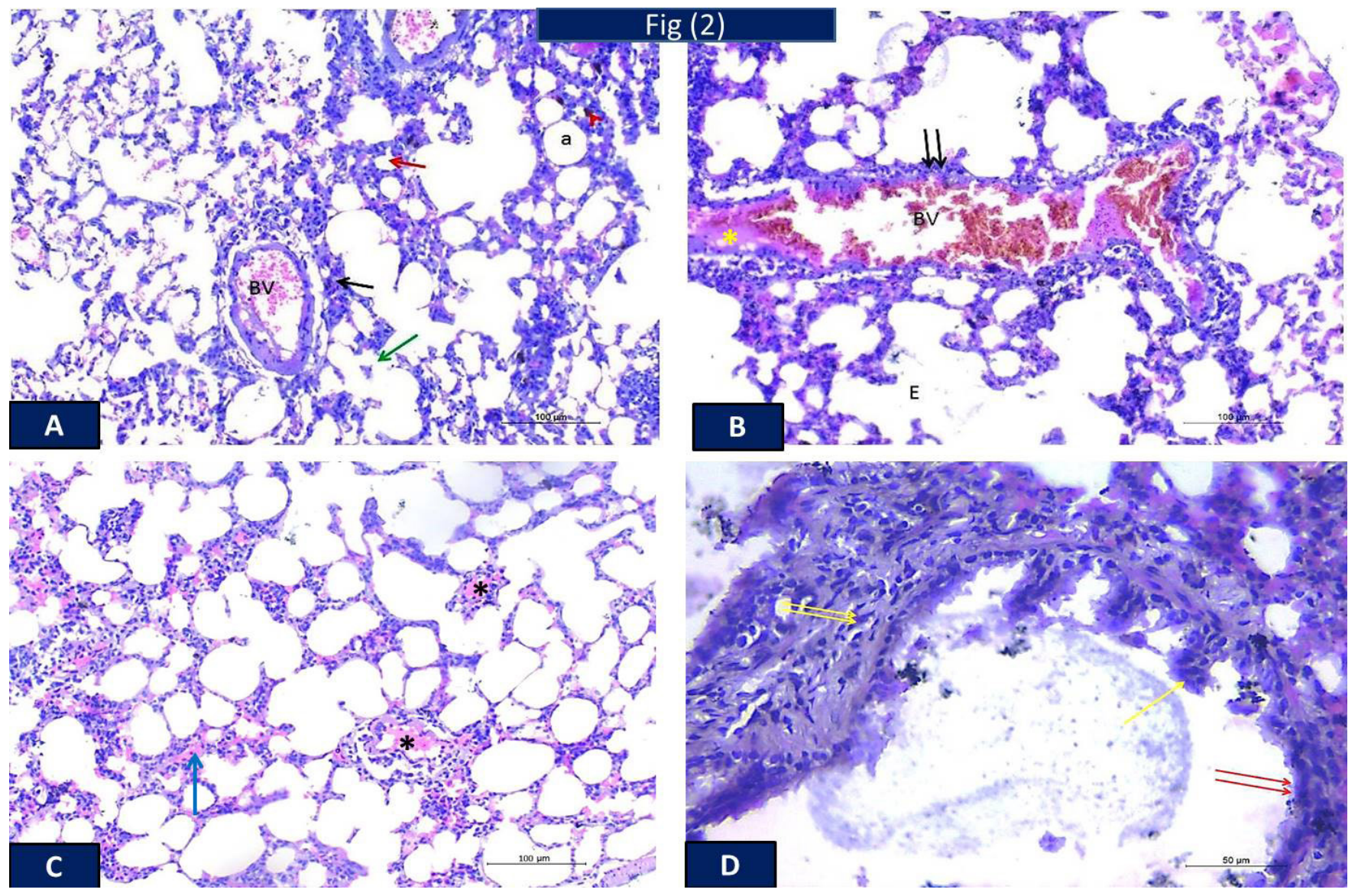

Fig 2: Photomicrographs of I/R group:- (A, B and C): showing unevenly alveolar spaces; some are compressed (red arrow) and others showing compensatory dilatation (a) with thickened and massively infiltrated inter-alveolar septa with inflammatory cells (black arrow). Destructed septa (green arrow) are also noticed in addition to deposition of brown particles mostly hemosiderin deposition (red arrow head), congested blood vessels (BV) with perivascular inflammatory infiltration (double black arrows) and perivascular edema (yellow star). In addition, emphysema (E), intra-alveolar (black stars) and interstitial (blue arrow) edema are also observed (HxandE X 20). (D): revealing peri-bronchial inflammatory infiltrate (double yellow arrows) and focal sloughing of the bronchial epithelial cells (double red arrows) with presence of disorganized bronchial epithelial lining (yellow arrow) (HxandE X 40). 


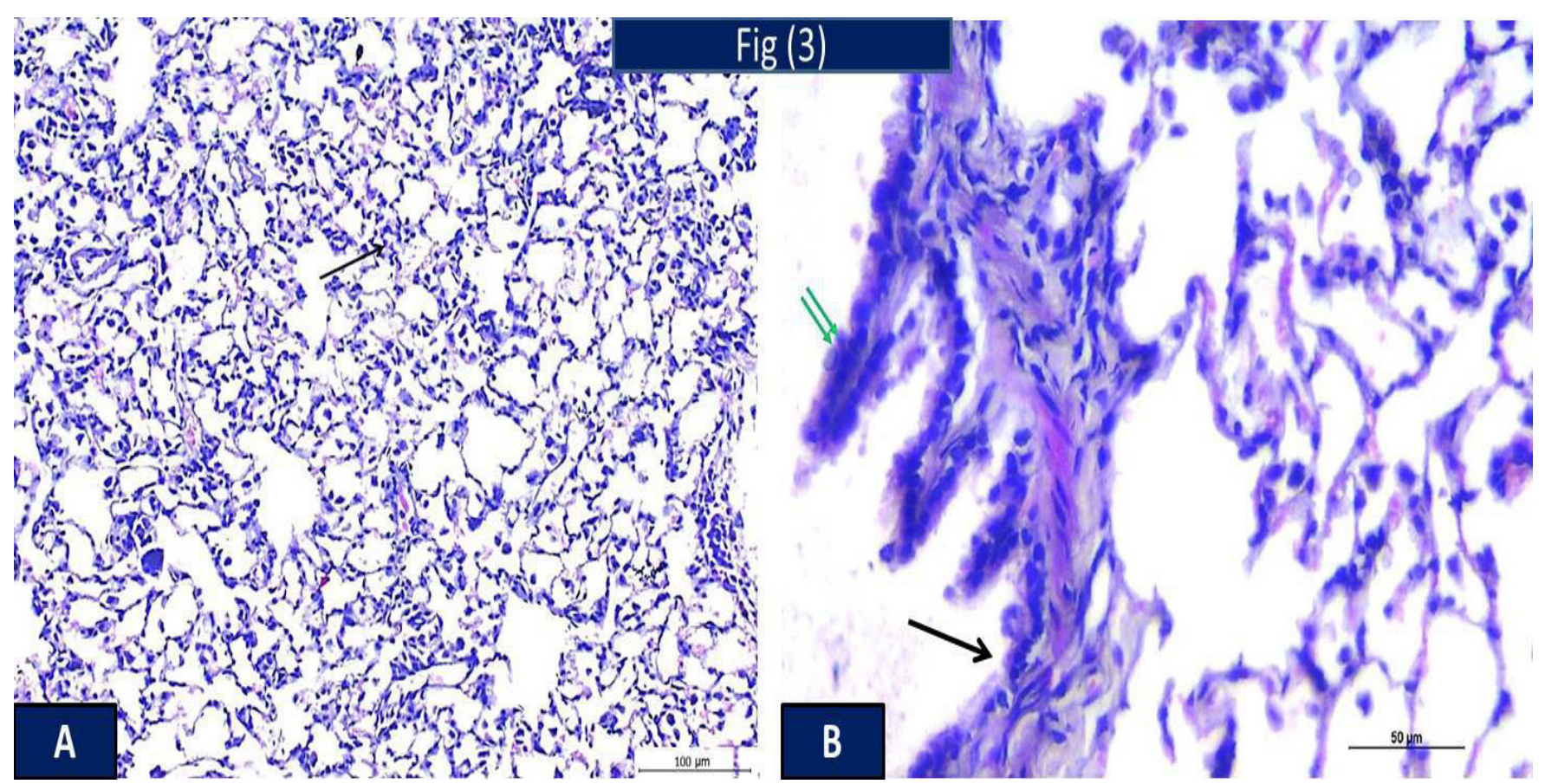

Fig 3: Photomicrographs of $I / R$ group pretreated with pomegranate peel powder:- (A): showing more or less normal lung architecture except for some interalveolar inflammatory infiltrate (black arrow) (HxandE X 20). (B): revealing a bronchus lined with respiratory epithelium (double green arrows) similar to that of the control group except for sloughing (black arrow) of small area of the bronchial epithelium (HxandE X 40).
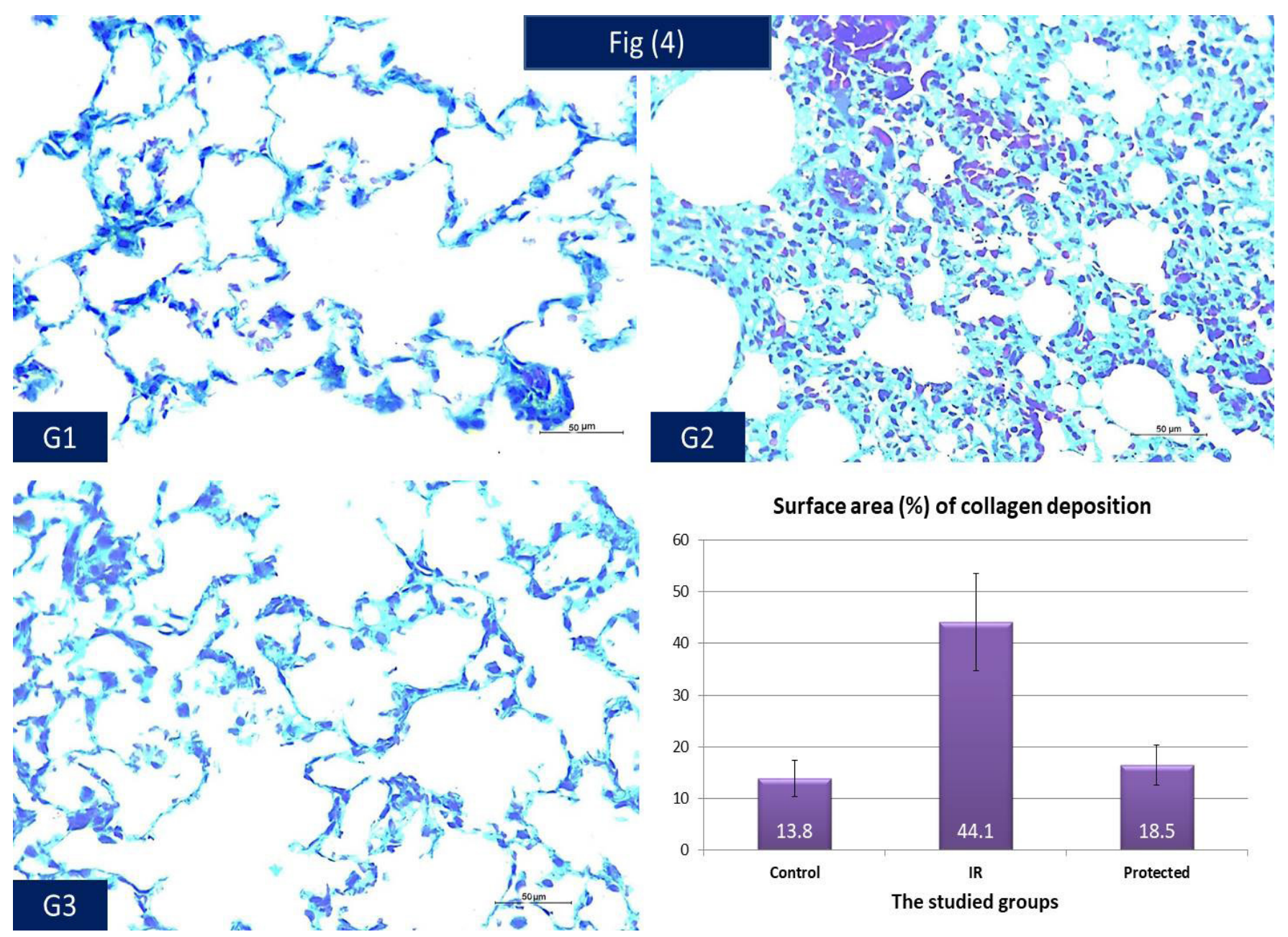

Fig 4: Photomicrographs of different experimental groups [(G1): control group, (G2): I/R group, (G3): I/R group pretreated with pomegranate peel powder] showing increase in the surface area of the collagen deposition in $\mathrm{I} / \mathrm{R}$ group in comparison to the other groups (Masson Trichrome $\mathrm{X} 40$ ). 

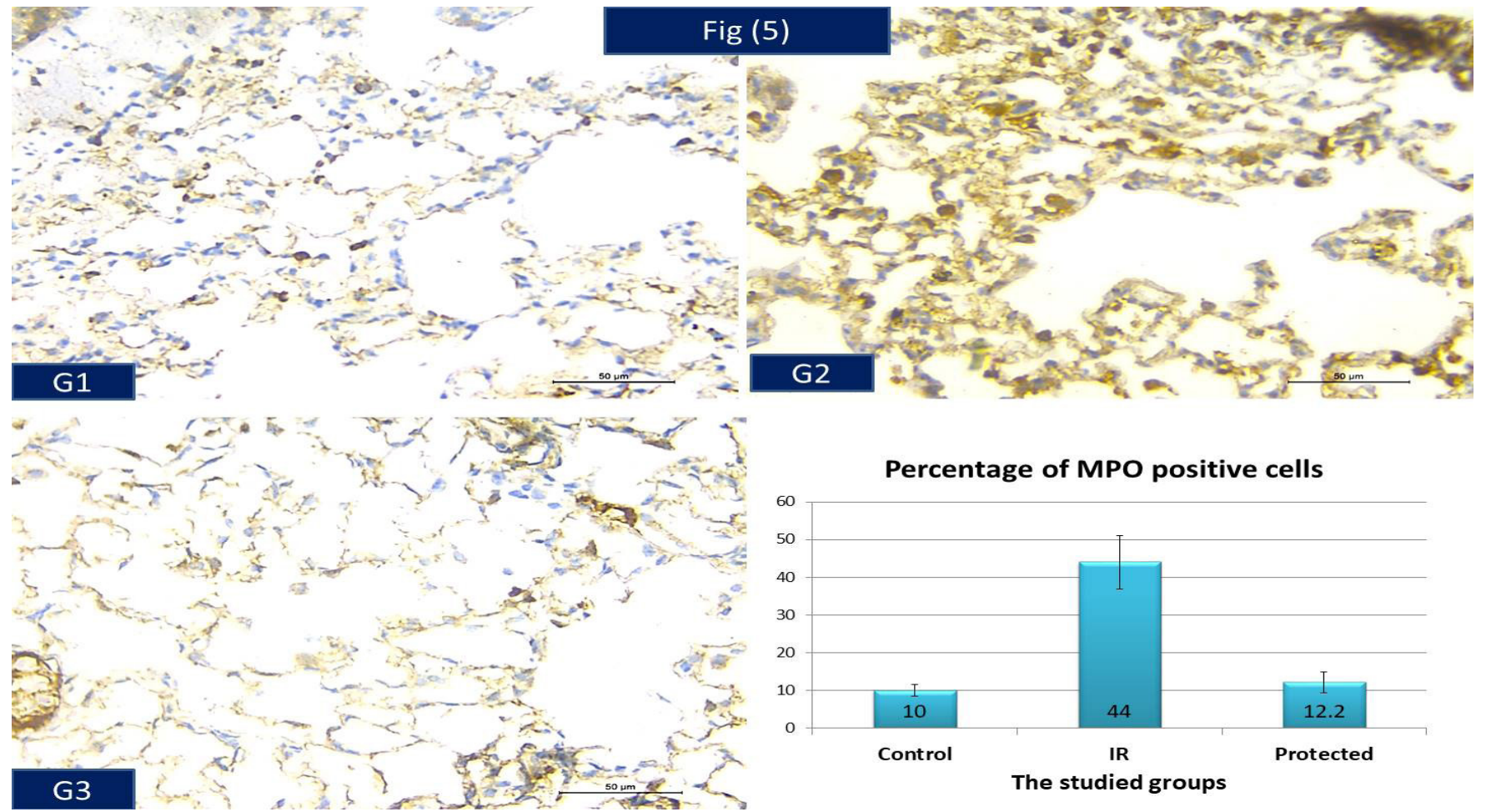

Fig 5: Photomicrographs of different experimental groups [(G1): control group, (G2): I/R group, (G3): I/R group pretreated with pomegranate peel powder] showing increase in the number of MPO positive cells in I/R group in comparison to the other groups (X 40).
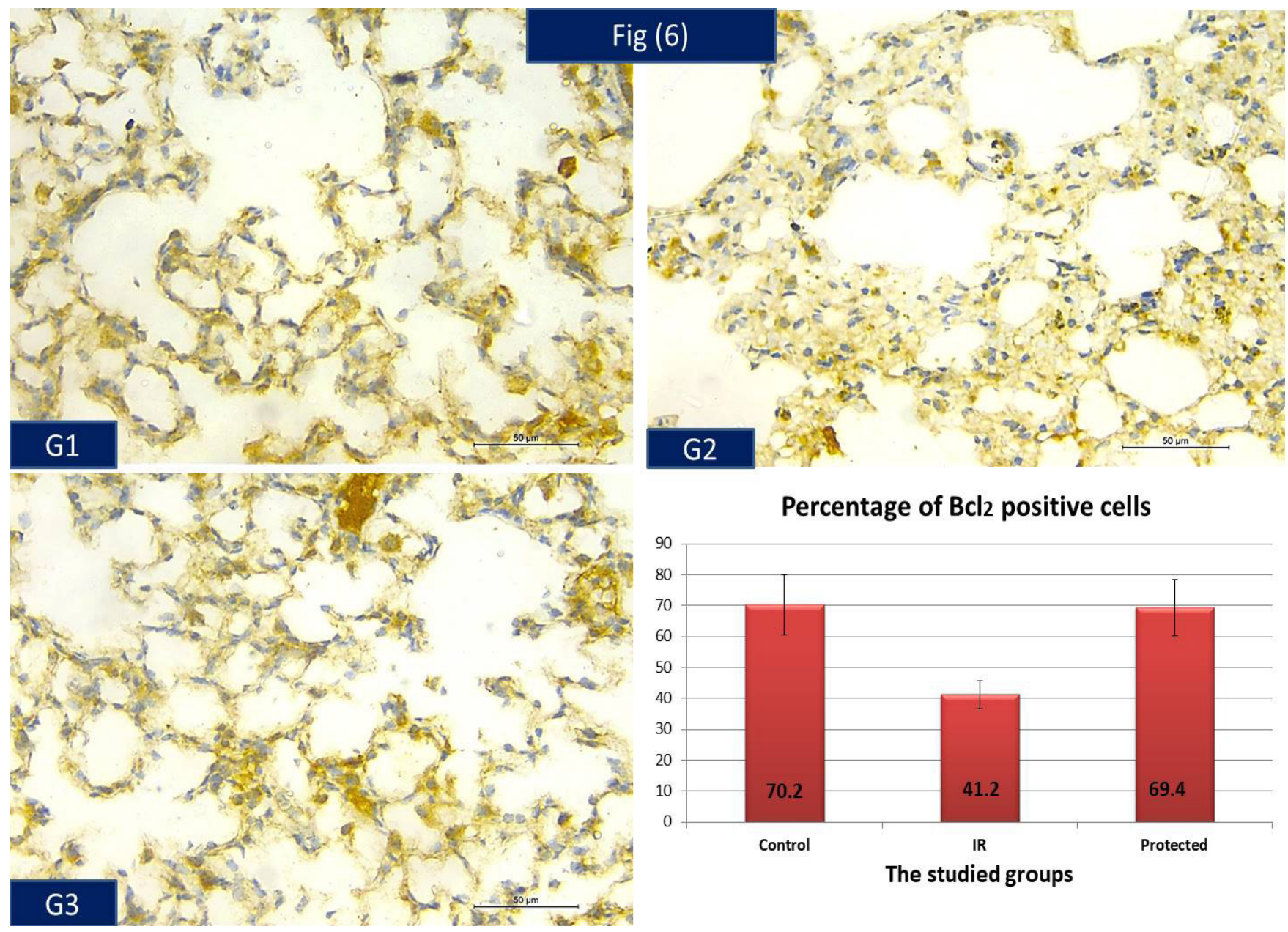

\section{Percentage of Bcl2 positive cells}

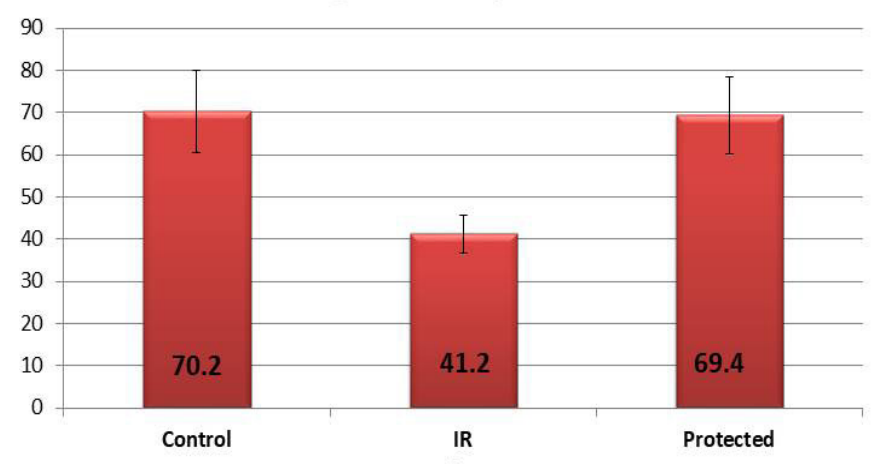

The studied groups

Fig 6: Photomicrographs of different experimental groups [(G1): control group, (G2): I/R group, (G3): I/R group pretreated with pomegranate peel powder] showing decrease in the number of Bcl2 positive cells in I/R group in comparison to the other groups (X40). 


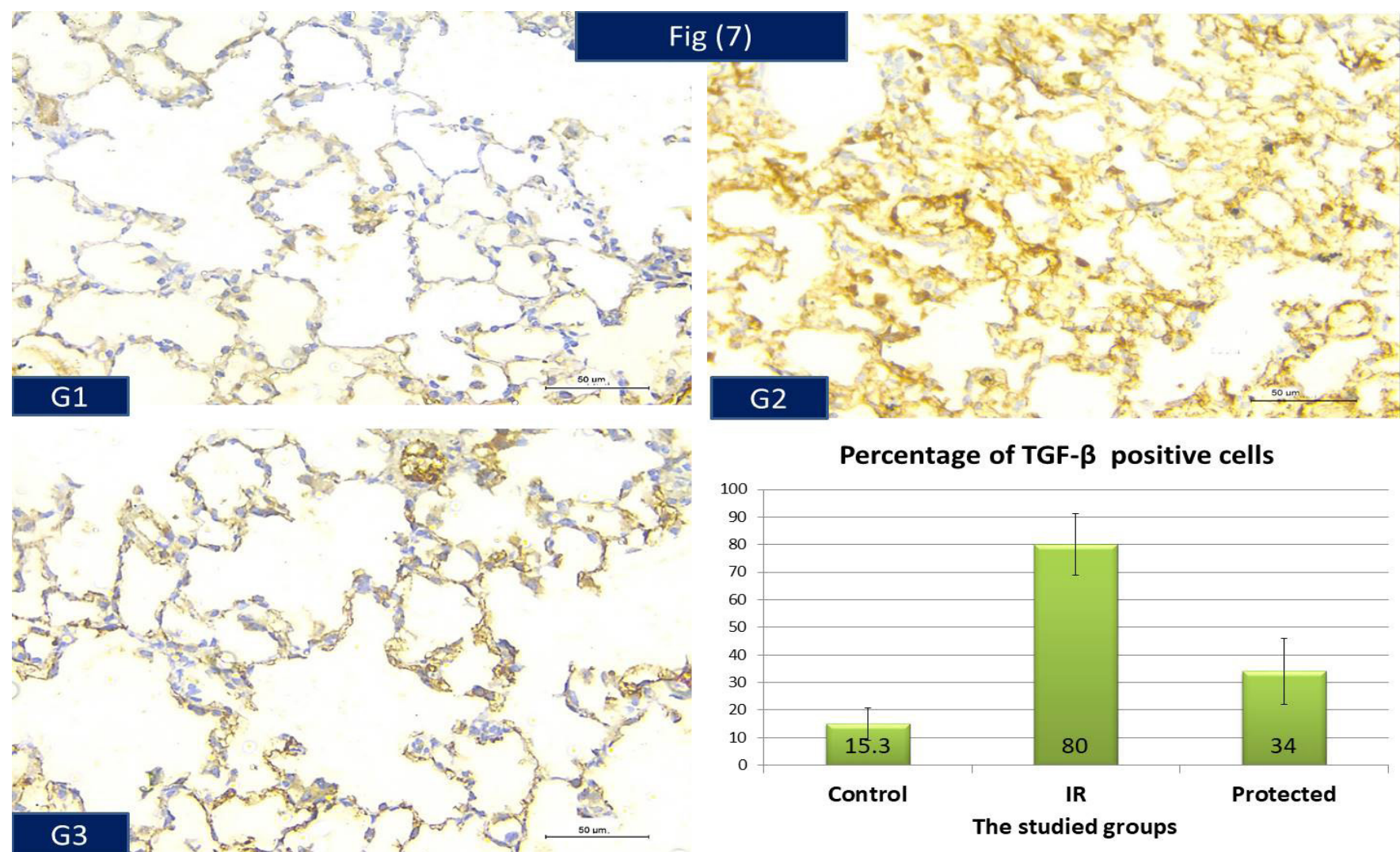

Fig 7: Photomicrographs of different experimental groups [(G1): control group, (G2): I/R group, (G3): I/R group pretreated with pomegranate peel powder] showing increase in the number of TGF- $\beta$ positive cells in I/R group in comparison to the other groups (X40).

Table 1: Malondialdehyde (MDA) level among the three studied groups

\begin{tabular}{|c|c|c|c|c|c|}
\hline & \multicolumn{3}{|c|}{ The studied groups } & \multirow[t]{2}{*}{$\mathrm{U}$} & \multirow[t]{2}{*}{$P$ value } \\
\hline & Control & $\mathrm{I} / \mathrm{R}$ & Protected & & \\
\hline MDA & & & & 2.69 & $0.008^{\mathrm{a}}$ \\
\hline $\mathrm{X} \pm \mathrm{SD}$ & $0.16 \pm 0.02$ & $2.16 \pm 0.18$ & $0.45 \pm 0.03$ & 2.61 & $0.009^{\mathrm{b}}$ \\
\hline Range & $0.123-0.186$ & $1.99-2.46$ & $0.395-0.486$ & 2.35 & $0.02^{\mathrm{c}}$ \\
\hline
\end{tabular}

$\mathrm{X}=$ Mean, $\mathrm{SD}=$ standard deviation, $\mathrm{U}=$ Mann Whitney $\mathrm{U}$ test

$\mathrm{a}=$ comparing $\mathrm{I} / \mathrm{R}$ group and control group

$\mathrm{b}=$ comparing $\mathrm{I} / \mathrm{R}$ group and protected group

$\mathrm{c}=$ comparing control group and protected group

\section{MDA}

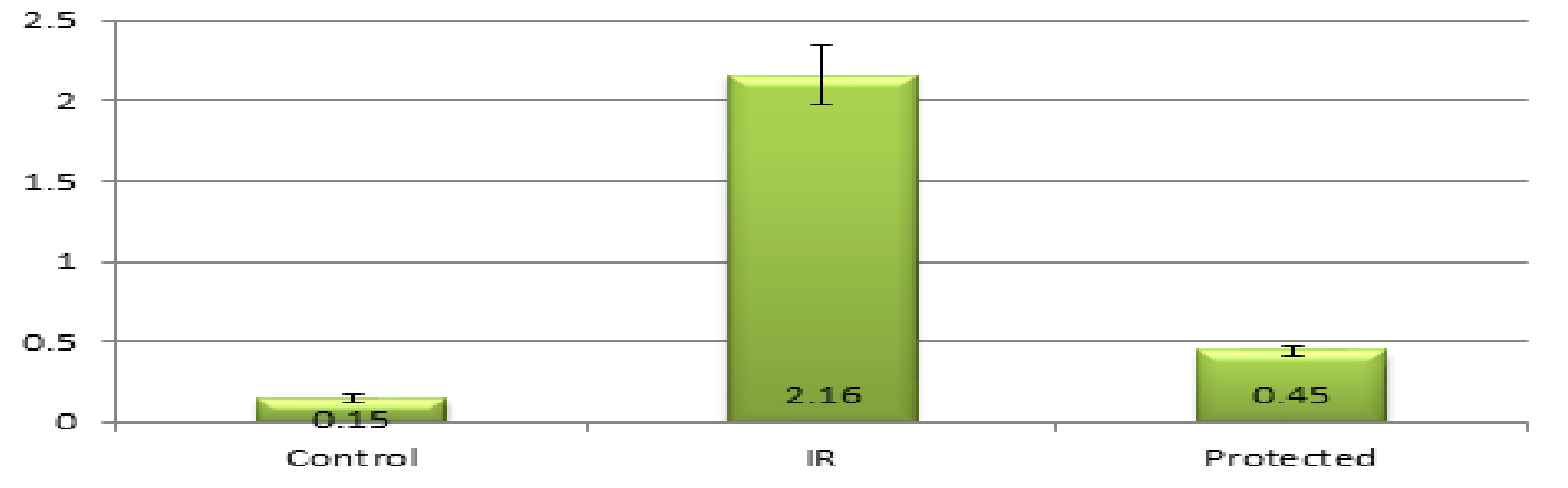

Histogram 1: Serum level of malondialdehyde (MDA) in control, I/R group and protected groups. 
Table 2: Comparison of the three studied groups regarding the thickness of the inter-alveolar septa (in pixels):

\begin{tabular}{lccccc}
\hline & & The studied groups & U & \\
\hline & Control & $\mathrm{I} / \mathrm{R}$ & Protected & & \\
\hline Thickness & & & 2.51 & $0.01^{\mathrm{a}}$ \\
$\mathrm{X} \pm \mathrm{SD}$ & $0.047 \pm 0.012$ & $0.341 \pm 0.092$ & $0.043 \pm 0.011$ & 2.71 & $0.008^{\mathrm{b}}$ \\
Range & $0.03-0.10$ & $0.098-0.508$ & $0.01-0.081$ & 0.45 & $0.59^{\mathrm{c}}$ \\
\hline
\end{tabular}

$\mathrm{X}=$ Mean, $\mathrm{SD}=$ standard deviation, $\mathrm{U}=$ Mann Whitney $\mathrm{U}$ test

$\mathrm{a}=$ comparing $\mathrm{I} / \mathrm{R}$ group and control group

$\mathrm{b}=$ comparing $\mathrm{I} / \mathrm{R}$ group and protected group

$\mathrm{c}=$ comparing control group and protected group

\section{Thickness of interalveolar septum}

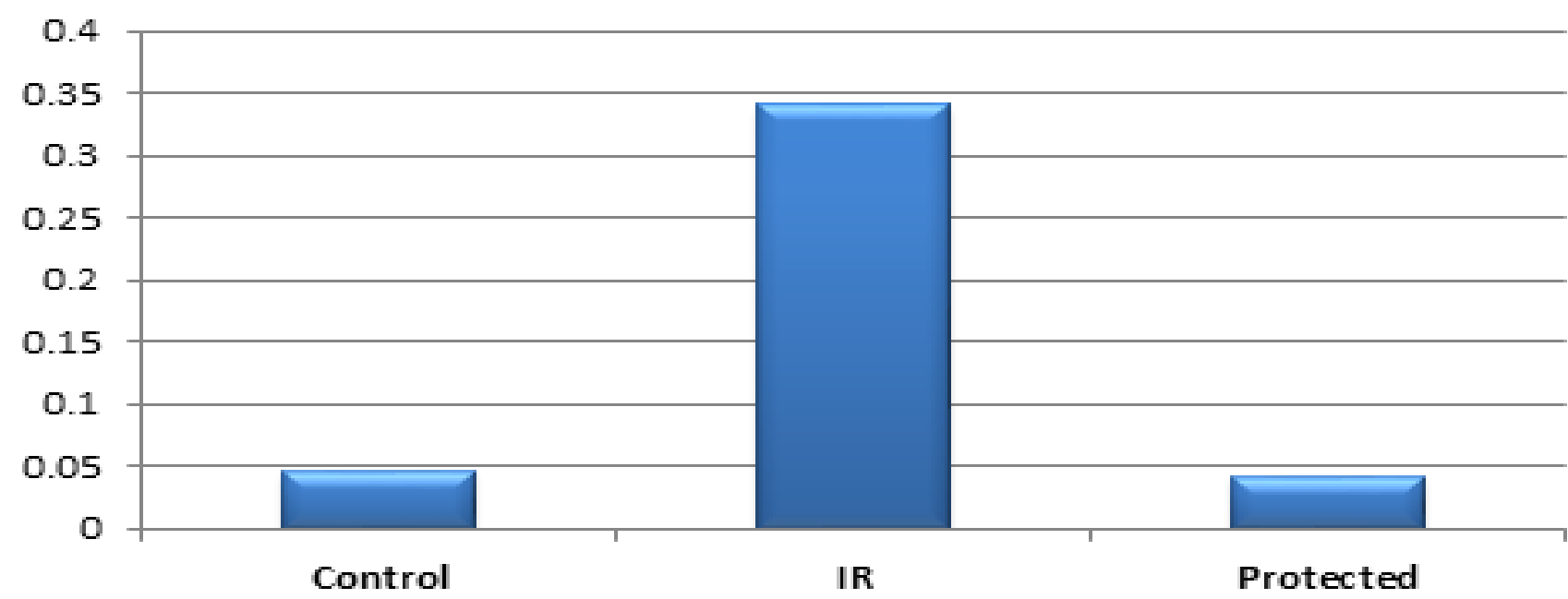

The studied groups

Histogram 2: Thickness of the inter-alveolar septa in control, I/R group and protected groups.

Table 3: Lung injury score among the three studied groups

\begin{tabular}{lccccc}
\hline & & The studied groups & U & \\
\hline & Control & I/R & Protected & & \\
\hline Score & & & 3.91 & \\
$\mathrm{X} \pm \mathrm{SD}$ & $0.6 \pm 0.12$ & $2.60 \pm 0.52$ & $0.80 \pm 0.18$ & 3.98 & $<1^{\mathrm{a}}$ \\
Range & $0-1$ & $2-3$ & $0-1$ & 0.95 & $0.34^{\mathrm{c}}$ \\
\hline
\end{tabular}

$\mathrm{a}=$ comparing $\mathrm{I} / \mathrm{R}$ group and control group

$\mathrm{b}=$ comparing $\mathrm{I} / \mathrm{R}$ group and protected group

$\mathrm{c}=$ comparing control group and protected group

Table 4: Surface area (\%) of collagen deposition: among the three studied groups

\begin{tabular}{|c|c|c|c|c|c|}
\hline & \multicolumn{3}{|c|}{ The studied groups } & \multirow[t]{2}{*}{$\mathrm{U}$} & \multirow[t]{2}{*}{ Pvalue } \\
\hline & Control & $\mathrm{I} / \mathrm{R}$ & Protected & & \\
\hline Surface area $(\%)$ of collagen deposition: & & & & 3.78 & $<0.001^{\mathrm{a}}$ \\
\hline $\mathrm{X} \pm \mathrm{SD}$ & $13.8 \pm 3.52$ & $44.1 \pm 9.46$ & $18.5 \pm 4.28$ & 3.79 & $<0.001^{\mathrm{b}}$ \\
\hline Range & $9-19$ & $28-60$ & $12-25$ & 2.31 & $0.02^{\mathrm{c}}$ \\
\hline
\end{tabular}

$\mathrm{X}=$ Mean, $\mathrm{SD}=$ standard deviation, $\mathrm{U}=$ Mann Whitney $\mathrm{U}$ test

$\mathrm{a}=$ comparing $\mathrm{I} / \mathrm{R}$ group and control group

$\mathrm{b}=$ comparing $\mathrm{I} / \mathrm{R}$ group and protected group

$\mathrm{c}=$ comparing control group and protected group 
Table 5: Immunohistochemistry results among the three studied groups

\begin{tabular}{|c|c|c|c|c|c|}
\hline & \multicolumn{3}{|c|}{ The studied groups } & \multirow[t]{2}{*}{$\mathrm{U}$} & \multirow[t]{2}{*}{ Pvalue } \\
\hline & Control & $\mathrm{I} / \mathrm{R}$ & Protected & & \\
\hline MPO positive cells $(\%)$ & & & & 2.61 & $0.009^{\mathrm{a}}$ \\
\hline $\mathrm{X} \pm \mathrm{SD}$ & $10.0 \pm 1.58$ & $44.0 \pm 7.07$ & $12.20 \pm 2.77$ & 2.53 & $0.01^{\mathrm{b}}$ \\
\hline Range & $8-12$ & $36-52$ & $9-15$ & 1.27 & $0.21^{\mathrm{c}}$ \\
\hline Bcl2 positive cells $(\%)$ & & & & 2.69 & $0.008^{\mathrm{a}}$ \\
\hline $\mathrm{X} \pm \mathrm{SD}$ & $70.2 \pm 9.73$ & $41.2 \pm 4.49$ & $69.4 \pm 9.18$ & 2.41 & $0.02^{\mathrm{b}}$ \\
\hline Range & $59-82$ & $35-45$ & $58-79$ & 0.10 & $0.92^{\mathrm{c}}$ \\
\hline TGF- $\beta(\%)$ & & & & 2.81 & $0.007^{\mathrm{a}}$ \\
\hline $\mathrm{X} \pm \mathrm{SD}$ & $15.3 \pm 2.77$ & $80.0 \pm 11.18$ & $34.0 \pm 8.22$ & 2.61 & $0.009^{\mathrm{b}}$ \\
\hline Range & $10-22$ & $65-95$ & $27-47$ & 2.67 & $0.01^{\mathrm{c}}$ \\
\hline
\end{tabular}

$\mathrm{X}=$ Mean, $\mathrm{SD}=$ standard deviation, $\mathrm{U}=$ Mann Whitney $\mathrm{U}$ test

$\mathrm{a}=$ comparing $\mathrm{I} / \mathrm{R}$ group and control group

$\mathrm{b}=$ comparing $\mathrm{I} / \mathrm{R}$ group and protected group

$\mathrm{c}=$ comparing control group and protected group

\section{DISCUSSION:}

Ischemia of the extremity is a major problem that may lead to a high incidence of morbidity and mortality. Thrombosis and embolism are the main causes of the acute limb ischemia. In addition, trauma, orthopedic surgery and free flap reconstruction frequently cause ischemia reperfusion (I/R) injury that affects various organs ${ }^{[13]}$. Therefore, it is a major problem that threatens the life. As yet, no reports have been documented on the protective effect of pomegranate peel powder as a natural element on the damaged lung tissue as a result of skeletal muscle I/R.

The period of the ischemia and subsequent reperfusion used in this study was based on previous studies that evaluated the lesions of remote organs ${ }^{[5,14,15]}$. The results of this research clarified that $\mathrm{I} / \mathrm{R}$ caused severe lung damage in the form of vascular congestion with subsequent hemosiderin deposition, massive inflammatory infiltrate, edema, emphysema, alveolar damage with thickened interalveolar septa and disrupted bronchial epithelium. These results were in agreement with other researches ${ }^{[14,15]}$ that reported occurrence of acute lung injury following hind $\operatorname{limb} \mathrm{I} / \mathrm{R}$ in rats.

These changes may be attributed to generation of free radicals from reperfusing tissues that led to a state of oxidative stress affecting the lung tissue as confirmed in this study by increased level of malondialdehyde (MDA). Earlier study ${ }^{[16]}$ revealed that the reduction of oxygen supply to the tissues led to accumulation of metabolites in the cells as a result of ischemia and hence damage of vital organs post-reperfusion.

Furthermore, it was reported that during ischemia, neurtophils and macrophages produced reactive oxygen species (ROS) which in turn activated nicotinamide adenine dinucleotide phosphate (NADPH) and proinflammatory cytokines ${ }^{[17]}$. The pro-inflammatory molecules could induce direct tissue damage and activate the leukocytes and thereby promote their sequestration in organs susceptible to leukocyte mediating injury such as the lung alveolar capillary bed, leading to endothelial cell injury and increased vascular permeability as mentioned by other researchers ${ }^{[18]}$.

Moreover, it was clarified that excess ROS led to protein and DNA damage that might directly damage cellular membranes by lipid peroxidation ${ }^{[19]}$. Malondialdehyde, an end product derived from the peroxidation of polyunsaturated fatty acids and related esters, was considered to be an indicator for lipid peroxidation as mentioned in previous study ${ }^{[20]}$. Furthermore, other study ${ }^{[5]}$ referred the damage of the remote organs to the depletion of antioxidant capacity of the body that occurred as a result of overproduction of ROS.

Although many studies have been performed to demonstrate the systemic effect of $I / R$, the underlying mechanisms are not well established. In this study, significant increase in MPO and TGF- $\beta$ expressions with significant decrease in the expression of $\mathrm{BCl} 2$ in the lung tissue following skeletal muscle $\mathrm{I} / \mathrm{R}$ was confirmed. So, we suggested that they played important roles in the pathogenesis of acute lung injury following skeletal muscle I/R. These changes may be due to the increase of ROS within the lung tissues.

This was in line with other researchers ${ }^{[5]}$ who stated that MPO was associated with an overproduction of ROS and they considered MPO as an index of accumulated activated leukocytes in the tissues that led to depletion of antioxidant capacity of the body. In addition, it was demonstrated that MPO was a local mediator of tissue damage and the resulting inflammation and hence was considered to be an important target in the treatment of inflammatory condition $^{[21]}$.

In this study, the significant decrease of Bcl2, an antiapoptotic marker, in the lung tissue of $\mathrm{I} / \mathrm{R}$ group indicated a great correlation between the apoptosis-related genes and lung injury induced by skeletal muscle I/R. This could be explained by earlier studies as they suggested that mitochondria played an important role in the survival/death 
of cells and that the opening of mitochondrial permeability transition pore could be regulated through reducing free radicals and regulating $\mathrm{Bax}$ and $\mathrm{Bcl} 2$ expression ${ }^{[22]}$. They added that the oxygen free radicals directly caused structural damage of cells or opening of the mitochondrial permeability transition pore in I/R injury ${ }^{[23]}$.

In this research, the significant increase in TGF- $\beta$ in the lung tissue of $I / R$ group suggested to be one of the underlying mechanisms that reflected some of the histopathological lung changes. This was in agreement with other researchers ${ }^{[24]}$ who considered the TGF- $\beta$ as a cytokine secreted by different cells as alveolar macrophage, endothelium, epithelium and fibroblast especially after multiple alveolar injuries as one of the profibrotic cytokines. In addition, previous study ${ }^{[25]}$ clarified that TGF- $\beta$ was a critical mediator in the development of pulmonary edema by increased alveolar permeability and it was involved in several biological processes as cell proliferation, differentiation, extracellular matrix remodeling, inflammation, apoptosis and fibrosis.

Some investigators ${ }^{[26]}$ stated that growth factors were involved in organ repair by their increased synthesis or release from the damaged cells after I/R insult. They found that there was a positive relationship between growth factors and tissue repair, and that induction of endogenous TGF- $\beta$ by ischemia was necessary for tissue repair. They added that by the end of tissue repair, the level of TGF- $\beta$ was restored in tissue again.

Our results revealed highly significant increase of collagen deposition in $\mathrm{I} / \mathrm{R}$ group in comparison to that of control group. This may be attributed to occurrence of oxidative stress and increase of some pro-fibrotic cytokines in $\mathrm{I} / \mathrm{R}$ group as confirmed in this study by the significant increase of TGF- $\beta$.

However, there are no enough documented data on increased collagen deposition in the lung tissue following skeletal muscle $\mathrm{I} / \mathrm{R}$, it was postulated that following acute inflammation, excessive ROS could induce damaged pulmonary epithelia to secrete pro-inflammatory and profibrotic cytokines that could lead to imbalances between histone acetylation and deacetylation ${ }^{[27]}$. Moreover, it was mentioned that TGF- $\beta$ was the key mediator in the development of pulmonary fibrosis through its actions to induce collagen gene expression or synthesis by stimulation of fibroblast proliferation ${ }^{[28,29]}$.

It was suggested that the process of fibrosis was promoted by early pro-inflammatory mediators. So, blocking of these mediators might be one approach to attenuate fibrosis ${ }^{[30]}$.

Acute lung injury induced by hind limb $\mathrm{I} / \mathrm{R}$ was significantly mitigated by pomegranate peel powder administration in this study. There was an obvious decrease in the lung tissue edema, inflammatory infiltration, alveolar damage and other features of the lung injury to a great extent as confirmed by the decrease in the histological injury scoring. This may be contributed to the antioxidant, anti-inflammatory and anti-apoptotic and even anti-fibrotic effects of pomegranate peel powder as established in this study.

As confirmed in this research, pomegranate peel powder significantly lowered MDA level and so, improving the lipid peroxidation. Furthermore, it inhibited the cellular apoptosis in the lungs through up-regulation of $\mathrm{Bcl} 2$. In addition, it significantly down regulated both MPO and TGF- $\beta$ in the lung tissue following I/R. Moreover, pomegranate peel powder significantly decreased the collagen deposition in the lung via the decrease in TGF- $\beta$ expression in addition to its antioxidant effect.

However there are no documented researches on the protective effect of pomegranate peel powder on the lung injury induced by skeletal muscle I/R and its underlying mechanisms, some studies ${ }^{[31,32,33]}$ postulated that the pomegranate fruit and peel extract had the ability to suppress lipid peroxidation in addition to its role as an electron donor in scavenging free radicals. Furthermore, this was in agreement with Khadijeh et al. ${ }^{[34]}$ who investigated the antioxidant defense mechanism of pomegranate by reducing $\mathrm{I} / \mathrm{R}$ induced endoplasmic reticulum stress in rat kidneys.

In conclusion, the results of our study confirmed that pomegranate peel had a protective effect against lung injury induced by I/R. These effects might be, at least in part, due to the inhibition of ROS production, down-regulation of MPO and TGF- $\beta$ with up-regulation of $\mathrm{Bcl} 2$ in the lung tissues. So, we suggested the possibility of clinical application of pomegranate peel in I/R injury of the lung. Different dosages and alternative time protocols of pomegranate peel administration for lung injury induced by skeletal muscle $\mathrm{I} / \mathrm{R}$ should be investigated in future studies.

\section{REFERENCES}

1. Heuvel MG, Buurman WA, Bast A, van der Hulst RR. Review: ischaemia-reperfusion injury in flap surgery. J Plast Reconstr Aesthet Surg 2009; 62:721-726.

2. Macedo FIB, Miranda LEC. Role of ischemic preconditioning in liver transplant: a review of literature. Exp Clin Transplant 2010; 8:1-3.

3. Baykara B, Tekmen I. Ischemı reperfusion injury in liver. Deutsch Med Faculty J 2005; 19:185-194.

4. Kusaka J, Koga H, Hagiwara S, Hasegawa A. Age-de $\neg$ pendent responses to renal ischemiareperfusion injury. Jour $\neg$ nal of Surgical Research 2012; 172:153-158.

5. Takhtfooladi MA, Jahanshahi A, Sotoudeh A, Jahanshahi G, Takhtfooladi HA, Aslani K. Effect of tramadol on lung injury induced by skeletal muscle ischemia-reperfusion: an experimental study. J Bras Pneumol 2013; 39:434-439. 
6. Eltzschig HK, Collard CD. Vascular ischemia and reperfusion injury. Br. Med. Bull 2004; 70:71-86.

7. Ozgen M, Durgac C, Serce S, Kaya C. Chemical and antioxidant properties of pomegranate cultivars grown in Mediterranean region of Turkey. Food Chemistry 2008; 111:703-706.

8. Tzulker R, Glazer I, Bar-Ilan I, Holland D, Aviram M, Amir R. Antioxidant activity, polyphenol content, and related compounds in different fruit juices and homogenates prepared from 29 different pomegranate accessions. J Agr Food Chem 2007; 55:9559-9570.

9. Viuda-Martos M, Fernández-Lóaez J, Pérezálvarez JA. Pomegranate and its many functional components as related to human health: a review. Comprehensive Reviews in Food Science and Food Safety 2010; 9(6):635-654.

10. Afaq F, Saleem M, Krueger CG, Reed JD, Mukhtar H. Anthocyanin-and hydrolysable tannine-rich pomegranate fruit extract modulates MAPK and NF-kB pathways and inhibits skin tumorigenesis in CD-1 mice. Int J Cancer 2005; 13:423-433.

11. Ismail T, Akhtar S, Riaz M, Ismail A. Effect of pomegranate peel supplementation on nutritional, organoleptic and stability properties of cookies. Int J Food Sci Nutr 2014; 65:661-666.

12. Koksel O, Yildirim C, Cinel L, Tamer L, Ozdulger A, Bastürk M, Degirmenci U, Kanik A, Cinel I. Inhibition of poly (ADP-ribose) polymerase attenuates lung tissue damage after hind limb ischemia reperfusion in rats. Pharmacol Res 2005; 51:453-562.

13. Akdemir AFN, Gülçin İ, Karagöz B, Soslu R. Quercetin protects rat skeletal muscle from ischemia reperfusion injury. J Enzyme Inhib Med Chem 2016; 31:162-166.

14. Takhtfooladi H, Takhtfooladi M, Moayer F, Mobarakeh S. Melatonin attenuates lung injury in a hind limb ischemia-reperfusion rat model. Rev Port Pneumol 2015; 21:30-35.

15. Takhtfooladi H, Hesaraki S, Razmara F, Takhtfooladi MA, Hajizadeh $\mathrm{H}$. Effects of $\mathrm{N}$ acetylcysteine and pentoxifylline on remote lung injury in a rat model of hind-limb ischemia/ reperfusion injury. J Bras Pneumol 2016; 42:9-14.

16. Francisco Neto A, Silva JCCB, Fagundes DJ, Pericário S, Novo NF, Juliano Y, Moreira Neto AA. Oxidative alterations, total antioxidant status and nitric oxide study in rats submitted to ischemia and reperfusion of hind limbs. Acta Cir Bras 2005; 20:134-139.
17. Ucar G, Topaloglu E, Kandilci HB, Gümüsel B. Effect of ischemic preconditioning on reactive oxygen species-mediated ischemia--reperfusion injury in the isolated perfused rat lung. Clinical Biochemistry 2005; 38:681-684.

18. Koike K, Moore EE, Moore FA, Kim FJ, Carl VS, Banerjee A. Gut phospholipase A2 mediates neutrophil priming and lung injury after mesenteric ischemia reperfusion. Am J Physiol 1995; 268:397403.

19. Wang S, Wang C, Yan F, Wang T, He Y, Li H, Xia Z, Zhang Z. N-Acetylcysteine Attenuates Diabetic Myocardial Ischemia Reperfusion Injury through Inhibiting Excessive Autophagy. Mediators Inflamm 2017; Article ID 9257291.

20. Gaweł S, Wardas M, Niedworok E, Wardas P. Malondialdehyde (MDA) as a lipid peroxidation marker. Wiad Lek 2004; 57:453-455.

21. Aratani, Y. Myeloperoxidase: Its role for host defense, inflammation, and neutrophil function. Arch Biochem Biophys 2018; 640:47-52.

22. Qu M, Zhou Z, Chen C, Li M, Pei L, Yang J, Wang Y, Li L, Liu C, Zhang G, Yu Z, Wang D. Inhibition of mitochondrial permeability transition pore opening is involved in the protective effects of mortalin overexpression against beta-amyloidinduced apoptosis in SH-SY5Y cells. Neuroscience Research 2012; 72:94-102.

23. Halladin NL. Oxidative and inflammatory biomarkers of ischemia and reperfusion injuries. Danish Medical Journal 2015; 62:B5054.

24. Verrecchia F, Mauviel A. Transforming growth factor-beta and fibrosis. World J Gastroenterol 2007; 13:3056-3062.

25. Pittet JF, Griffiths MJ, Geiser T, Kaminski N, Dalton SL, Huang X, Brown LA, Gotwals PJ, Koteliansky VE, Matthay MA, Sheppard D. TGFbeta is a critical mediator of acute lung injury. J Clin Invest 2001; 107:1537-1544.

26. Fu XB, Yang YH, Sun TZ, Gu XM, Jiang LX, Sun XQ, Sheng ZY. Effect of intestinal ischemiareperfusion on expressions of endogenous basic fibroblast growth factor and transforming growth factor $\beta$ in lung and its relation with lung repair. World J Gastroenterol 2000; 6:353-355.

27. Rahman I, Marwick J, Kirkham P. Redox modulation of chromatin remodeling: impact on histone acetylation and deacetylation, NF-kappaB and pro-inflammatory gene expression. Biochem Pharmacol 2004; 68:1255-1267. 
28. Kolb M, Margetts PJ, Anthony DC, Pitossi F, Gauldie J. Transient expression of IL-1 $\beta$ induces acute lung injury and chronic repair leading to pulmonary fibrosis. J Clin. Invest 2001; 107:1529.

29. Martin TR, and Matute-Bello G. Experimental models and emerging hypotheses for acute lung injury. Crit Care Clin 2011; 27:735-752.

30. Guo H, Ji F, Liu B, Chen X, He J, Gong, J. Peiminine ameliorates bleomycin-induced acute lung injury in rats. Mol Med Rep 2013; 7:11031110

31. Singh R, Ahmed S, Malemud CJ, Goldberg VM, Haqqi TM. Epigallocatechin-3-gallate selectively inhibits interleukin- $1 \beta$-induced activation of mitogen activated protein kinase subgroup c-jun $\mathrm{N}$-terminal kinase (JNK) in human osteoarthritis chondrocytes. J Orthop Res 2003; 21:102-109.

32. Sudheesh S, Vijayalakshmi NR. Flavonoids from punica granatum-potential antiperoxidative agents. Fitoterapia 2005; 76:181-186.

33. Kaur G, Jabbar Z, Athar M, Alam MS. Punica granatum (pomegranate) flower extract possesses potent antioxidant activity and abrogates FeNTA induced hepatotoxicity in mice. Food Chem Toxicol 2006; 44:984-993.

34. Khadijeh H, Kazem P, Samira F, Alireza H, Mehrdad M, Naser MA, Mohammadhossein NS, Amir A. Pomegranate (Punicagranatum L.) reduces endoplasmic reticulum stress induced by renal ischemia/reperfusion injury in rat. Turk $\mathrm{J}$ Biol 2013; 37:464-471. 


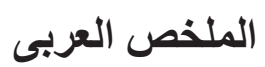

الدور الوقائي المحتمل لمسحوق قثر الرمان على إصابة رئة الجرذان الناتجة عن نقص التروية الاموية للعضلات الهيكلية ثم ضخهان

\section{رشا ممدوح سلامة ، منار علي فريد

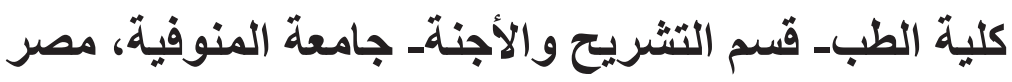

المقدمة: اصابة العضلات بنقص التروية الدموية ثم اعادة الضخ اثناء بعض العمليات الجر احية يؤدى الى فثل العديد من الاعضاء مما يسبب تعرض الحفة الحباه للخطر.

الهُف من البحث: دراسة الدور الوقائى المحتمل لمسحوق قثر الرمان على اصابة رئة الجرذان الناتجة عن نقص التروية

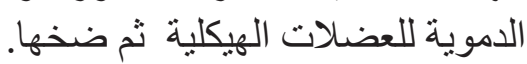

الطرق والأدوات: تم تقسيم ثلاثون ذكرا من الجرذان البيضاء إلى ثلاث مجموعات (مجموعة 1) ضابطة و (مجموعة 2 ) )

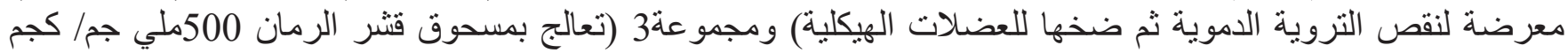

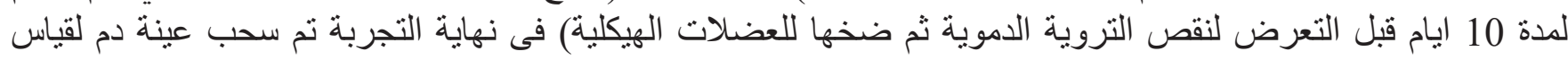

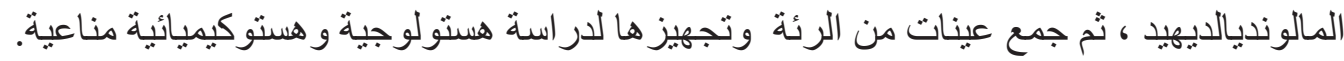

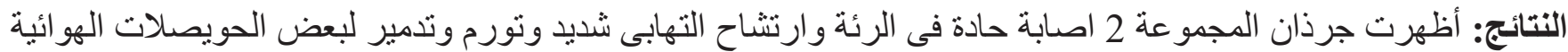

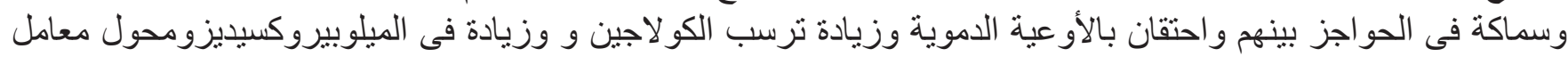

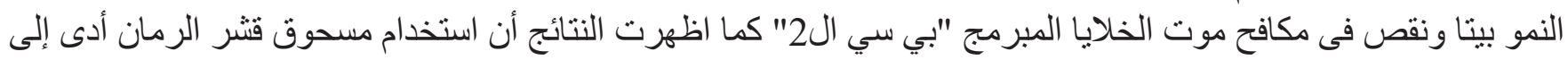
تحسن ملحوظ فى كل هذه التغير ات.

الخلاصة: مسحوق قثر الرمان له تأثيروقائى على الرئة بعد التعرض لنقص التروية الدموية ثم ضخها للعضلات. 